\title{
O CONTEXTO DE PRODUÇÃO NO GÊNERO VIDEOCLIPE DE ANÚNCIO PUBLICITÁRIO INSTITUCIONAL ${ }^{1}$
}

\author{
The Production Context Production in the Genre Video clip of institutional advertisement
}

\author{
Francieli de OLIVEIRA, UEL ${ }^{2}$
}

RESUMO: O presente artigo tem como objetivo a análise do contexto de produção do gênero videoclipe de anúncio publicitário institucional, fundamentado nos pressupostos teóricos do Interacionismo Sociodiscursivo (ISD) de Bronckart (1999/2012). Este trabalho constitui um modelo didático do gênero, desenvolvido em trabalho de dissertação de mestrado no curso de Estudos da Linguagem da UEL. Para o desenvolvimento desse estudo, fazemos uma revisão sobre questões de análise de produção textual, elaborado pelo ISD (BRONCKART, 1999/2012), e conceitos relacionados e esta abordagem. Apresentamos uma descrição dos elementos que compõe o gênero videoclipe de anúncio publicitário institucional (VAPI) para situá-lo em contexto de uso social e que possibilita ao leitor compreender em qual contexto o gênero é utilizado e quais suas características em termos de produção textual.

PALAVRAS-CHAVE: Interacionismo sociodiscursivo; gêneros textuais; videoclipe de anúncio publicitário institucional; contexto de produção.

\begin{abstract}
This article aims at presenting the analysis of the context production in the institutional advertising video clip (IAVC), based on the Socio-discursive Interactionism theory (SDI) by Bronckart (1999/2012). This present article is part of a didactic model, developed in a master's course thesis in Language Studies course at UEL. For the development of this research, it was revisedd the issues of textual analysis, elaborated by SDI (BRONCKART, 1999/2012) and the concepts related to this approach. It is presented a description of the elements that compose the genre IAVC in order to show it in the social context where it is used and that enables the reader to understand in which context the genre is used and what its characteristics in terms of production are.
\end{abstract}

KEY-WORDS: Socio-discursive Interacionism; textual genres; institutional advertising video clip; production context.

\section{INTRODUÇÃO}

O objetivo do trabalho é apresentar a análise do contexto de produção do gênero videoclipe de anúncio publicitário institucional, embasada pela abordagem do Interacionismo Sociodiscursivo (ISD) de Bronckart (1999/2012).

\footnotetext{
${ }^{1}$ Este trabalho compõe o trabalho de dissertação em Estudos da Linguagem na UEL orientado por Vera Lúcia Lopes Cristovão.

${ }^{2}$ Mestranda em Estudos da Linguagem - UEL.
} 
Para o ISD, quando atores em uma comunidade, fazemos a interação por meio de textos e variam de acordo com o contexto em que estamos interagindo. Cada situação de linguagem pode determinar o gênero a ser apropriado e que melhor se enquadra aquela situação e vice-versa. A forma como escolhemos é pelo conhecimento pré-existente em nós e na sociedade de modo que já encontramos modelos pré-determinados dos quais nos apropriamos e adequamos à nova ação linguística.

Discutimos na primeira seção deste trabalho questões de uso de gêneros textuais em interações sociais e da linguagem em uso. Posteriormente, definimos o que é texto, segundo o ISD. Em seguida, apresentamos as circunstâncias de análise dos gêneros por meio do contexto de produção de acordo com esta essa perspectiva teórica. Mostramos também qual o gênero escolhido e sua definição. Por fim, seguimos para a apresentação dos resultados da análise do contexto de produção desse gênero denominado videoclipe de anúncio publicitário institucional (VAPI), que compõem a dissertação de mestrado.

\section{INTERAGINDO POR MEIO DE TEXTOS}

Quando participantes de uma comunidade e atores comunicativos nestas e tantas outras determinadas situações de interação social/ação de linguagem, fazemos uso de textos interagirmos socialmente, portanto "o agir linguageiro se traduz em um texto" (BRONCKART, 2008, p. 87). Quando em interação, nos baseamos em modelos pré-determinados de textos, em todas as situações comunicativas desde o contato mais simples, como um bilhete, até o mais complexo, como por exemplo, em diálogos ou palestras. Utilizamo-nos desses modelos pré-determinados para agirmos de modo que sejamos socialmente ativos e possamos nos fazer entender por meio dos gêneros. Quevedo-Camargo (2008) argumenta que "a apropriação dos gêneros é um mecanismo fundamental de socialização e de possibilidade de inserção prática dos indivíduos nas atividades comunicativas humanas" (p. 129). Portanto, sempre quando em ação de linguagem nos apropriamos dos gêneros para que possamos efetivar nossas intenções comunicativas, e nos orientamos por intenções e razões para serem utilizados em determinadas situações de interação. 


\section{AFINAL, O QUE É TEXTO?}

Bronckart (1999/2012, p. 137; 2008, p. 87) argumenta que o texto é "toda unidade de produção verbal que veicula uma mensagem linguisticamente organizada e que tende a produzir um efeito de coerência em seu destinatário... é a unidade comunicativa de nível superior". Segundo o autor, essa acepção pode ser aplicada tanto à produção escrita como a oral, pois o agir é verbal e não-verbal. Os indivíduos de uma interação mobilizam recursos de uma língua, como por exemplo, a gramática, e consideram um "o modelo de organização textual” (BRONCKART, 2006, p. 13) dessa mesma língua. No plano do contexto podemos distinguir ainda, segundo Bronckart (1999/2012) duas categorias textuais, os "originalmente" orais e escritos (p. 185). Nós usamos nesse trabalho o termo "originalmente" porque todo texto originalmente oral pode ser transcrito e o texto originalmente escrito pode ser transformado em texto oral. Os textos são resultado da ação da linguagem nas formações sociais e são produzidos de acordo com os "objetivos, interesses e questões específicas” (p. 137) sendo essas características que podem determinar qual o texto a ser utilizado em determinada situação e, após seu uso, podem servir como modelo para que outros actantes possam produzir seus próprios textos com base nele (BRONCKART, 1999/2012).

Schneuwly (2004) apresenta como parâmetros para a escolha dos gêneros a finalidade do uso, os destinatários e o conteúdo temático do texto. O sujeito chega a uma decisão num conjunto possível de textos e que é denominado por Bronckart (2008) de "arquitexto de uma comunidade linguageira" (p. 88). Assim que escolhe o gênero a utilizar na interação, o adapta e coloca em uso.

Portanto, o gênero de texto é adaptado às atividades praticadas e por isso, "é um instrumento" (SCHNEUWLY, 2004, p. 20). O autor ressalta que o interacionismo sociodiscursivo visa à ação do ator social como sendo tripolar, entre o sujeito e a situação de comunicação há o instrumento, nesse caso o gênero. Schneuwly (2004) defende que esse instrumento além de intermediar a atividade ele também a representa, a materializa tornando-a possível, o pensamento se torna atingível por meio do gênero (SCHNEUWLY, 2004, p. 21). Contudo, para que isso aconteça é necessário que o sujeito se aproprie do instrumento e crie os esquemas de utilização, que são as formas estruturais dos gêneros dependendo das situações de uso.

Segundo Bronckart (2006), os gêneros não podem ser considerados estáveis porque mudam em relação ao tempo e às novas formações sócio-discursivas, mas, de acordo com Schneuwly (2004), os gêneros têm certa estabilidade, pois determinam o que deve ser dito, assim como, o que é falado ou será falado determina o gênero que será utilizado. Além disso, Bronckart (1996/2012) afirma que os gêneros são em grande infinitos e a sua classificação como sendo de um gênero 
específico não é delimitável, pois fazem parte da interação entre indivíduos e são constituídos por unidades muito variáveis.

\section{ANALISANDO OS GÊNEROS PARA COLOCAR EM USO}

Sendo os gêneros infinitos e adaptados a cada situação social e modificáveis historicamente, há uma possibilidade de classificação para a disponibilização de uma referência textual para posterior uso. Primeiramente, o gênero é um objeto de avaliação social e depende da verificação da situação social na qual ele será mobilizado e dependendo também do seu valor estético (BRONCKART, 2008). Portanto, o ator quando em determinada situação de linguagem deverá ter "um conhecimento pessoal e parcial do arquitexto da sua comunidade verbal e dos modelos dos gêneros nela disponíveis" (PEREIRA E GRAÇA, 2007, p. 180). Assim, o indivíduo poderá se apropriar do gênero apropriado para atuar e expressar naquela atividade de linguagem. Esse modelo é determinado por uma situação de análise, o contexto de produção. Para o ISD:

as atividades de linguagem em funcionamento nas coletividades humanas, que se desenvolvem no quadro de formações sociodiscursivas ... e nas quais participam agentes singulares, como sedes de ações de linguagem determinadas; os textos, como formas comunicativas globais e "finitas" constituindo os produtos concretos das ações de linguagem, que se distribuem em gêneros adaptados às necessidades das formações sociodiscursivas ..., permanecendo esses gêneros, cujo número e cujas fronteiras são por essência indeterminados, à disposição, como modelos, nesse construto sócio-histórico que é o intertexto (BRONCKART, 1999/2012).

Em outras palavras, os gêneros são distribuídos socialmente pelos atores sociais de acordo com a necessidade contextual, são meio de comunicação sendo instrumentos apropriados pelos atores para agirem no mundo e são disponibilizados após o uso como modelos, denominados de intertextos. Os mundos discursivos são definidos por Bronckart (1999/2012) como sendo os segmentos que constituem um gênero nos quais nos baseamos para que possamos elaborar um determinado gênero. Segundo Bronckart (1999/2012):

Esses mundos são sistemas de coordenadas formais que, de um lado, são radicalmente "outros" em relação aos sistemas de coordenadas dos mundos representados em que se desenvolvem as ações de agentes humanos, mas que, de outro, devem mostrar o tipo de relação que mantêm com esses mundos da atividade humana. ... chamaremos os mundos representados pelos agentes 
humanos de mundo ordinário e os mundos virtuais criados pela atividade de linguagem, de mundos discursivos (p. 151).

Os mundos discursivos são definidos pela situação de interação que criamos socialmente e pelo nosso imaginário que apropria-se daquela situação de comunicação. Para produzirmos um determinado gênero, fazemos uma análise da situação de produção e o elaboramos baseados no mundo real, que é o momento no qual o indivíduo se põe a produzir (BRONCKART, 1999/2012). Para que essa mobilização seja original é necessário que se utilizem as formas já existentes mesmo que elas respeitem ou não a organização textual ou interação social (ÉRNICA, 2007).

Segundo Bronckart (1999/2012, o Interacionismo Sociodiscursivo tem por objetivo

descrever... os mundos ou planos de enunciação assim como as operações psicológicas em que se baseiam e... as configurações de unidades linguísticas "que traduzem" esses mundos, no quadro de uma determinada língua natural (BRONCKART, 1999/2012, p. 151).

A análise do contexto de produção feita é no nível de ação de linguagem bem como de estrutura linguística e diferentemente das outras abordagens, o ISD considera o contexto social no qual o indivíduo se insere para agir comunicativamente, o ensino da estrutura linguística não é suficiente para que a interação seja efetiva. Por este motivo, é necessário a análise do contexto de produção de um gênero, pois ele é produzido contextualmente.

Bronckart (1999/2012) argumenta que para que haja produção de gêneros de texto é necessário uma "base de orientação a partir da qual um conjunto de decisões devem ser tomadas" (p. 92). Dessa forma, o agente escolherá entre os modelos que ele possui em sua mente qual é o melhor a ser utilizado de acordo com a situação vivida naquele momento. Para isso, ele irá movimentar o conhecimento prévio de mundo de duas formas. A primeira forma de mobilização é o contextual ou pela análise do conjunto de parâmetros físicos (BRONCKART, 2008), qual é o contexto no qual ele se encontra no momento de interação e se isso irá influenciar na organização do texto. A segunda forma são as representações do mundo temático e da mesma forma e/ou parâmetros sociossubjetivos e de que forma estes influenciam ou não no gênero novamente. $\mathrm{O}$ autor denomina essas formas como contexto de produção (1999/2012, p. 93) e este é determinado por fatores que estão em dois conjuntos: o mundo físico e o mundo social.

No contexto físico encontramos: 
O lugar de produção: o lugar físico em que o texto é produzido;

O momento de produção: a extensão do tempo durante a qual o texto é produzido;

O emissor (ou produtor, ou locutor): a pessoa (ou a máquina) que produz fisicamente o texto, podendo essa produção ser efetuada na modalidade oral ou escrita;

O receptor: a (ou as) pessoa(s) que pode $(\mathrm{m})$ perceber (ou receber) concretamente o texto. (BRONCKART, 1999/2012, p. 93).

O autor ressalta que se a situação for oral, é possível que os dois, emissor e receptor, estejam no mesmo ambiente sendo possível que o primeiro receba resposta imediata se esse for o caso. Se for distante se tornará um interlocutor e se não houver necessidade de resposta não é interlocutor.

No mundo social há duas posições o mundo social e o subjetivo nos quais respectivamente encontramos valores e a imagem que desejamos que o outro tenha de nós. Assim, de acordo com Bronckart (1999/2012) as situações do mundo social são:

O lugar social: no quadro de qual formação social, de qual instituição ou, de forma mais geral, em que modo de interação o texto é produzido ...

A posição social do emissor... qual é o papel social que o emissor desempenha na interação em curso...

A posição social do receptor... qual é o papel social atribuído ao receptor do texto...

O objetivo (ou os objetivos) da interação: qual é, do ponto de vista do enunciador, o efeito (ou os efeitos) que o texto pode produzir no destinatário? (BRONCKART, 1999/2012, p. 94)

Em outras palavras,

"contexto de produção" procura abranger os factores que funcionam como condições de possibilidade (lugares e tempo de produção, estatuto social do emissor e do receptor e objectivos da interação) que se apresentam ao agente no momento da realização de determinada acção de linguagem (PEREIRA E GRAÇA, 2007, p. 179).

Para Graça (2007) a ação de linguagem é direcionada pelo contexto de produção e determina as condições de produção do gênero. Para compreender melhor as questões de produção, Nascimento e Cristovão (2006) desenvolveram um esquema que compreende os dois níveis de análise de textos, segue a seguir: 


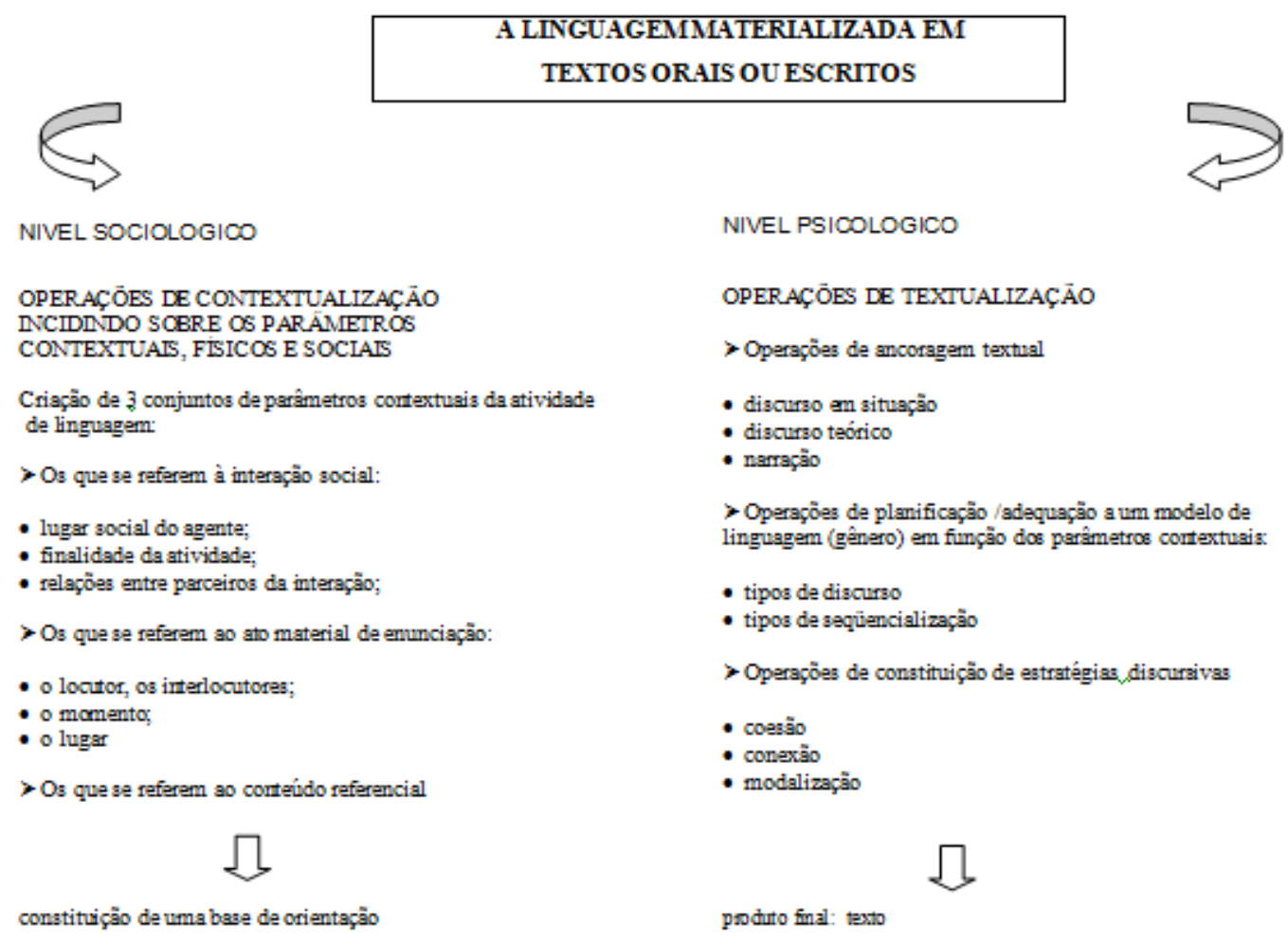

Fonte: NASCIMENTO e CRISTOVÃO (2006)

Para o desenvolvimento desse trabalho apresentamos apenas o contexto no nível sociológico ${ }^{3}$.

Para Bronckart (1999/2012) é necessário diferenciar o emissor do receptor de forma que são ambos os seres sociais e que preenchem um papel social, um único é responsável pela produção textual chamado de autor. Há outras vozes no texto que podem ser do próprio autor ou instituídas por outras vozes. Encontramos também a existência de uma mensagem que é recebida por um receptor e que tem uma função da linguagem. A produção de um texto possui objetivos infinitos e são influenciadas pela identidade do agente produtor desse texto. Os nossos conhecimentos sobre essas situações de interação são construídas por experiências de interação nas quais aprendemos a distinguir quais devemos ou não utilizar (BRONCKART, 1999/2012).

... a produção verba real provém da escolha de um gênero textual que parece ser adaptado à situação, por meio de empréstimo ao arquitexto (em um processo de adaptação de um modelo textual), e pela exploração desse modelo, levando-se em conta as propriedades sempre particulares da situação de produção do actante (em um processo de adaptação desse modelo) (BRONCKART, 2008, p. 88).

\footnotetext{
${ }^{3} \mathrm{O}$ trabalho de dissertação ainda está em andamento e, por isto, apresentamos somente esta fase do trabalho.
} 
Os conteúdos temáticos são determinados da mesma forma pela vivência do autor de modo ele é quem decidirá qual será o tema abordado. Eles podem ser de ordem social, do mundo físico ou ainda de ordem subjetiva e esses nunca serão "cópias idênticas das macro estruturas semânticas" (BRONCKART, 2008, p. 88). A ação de linguagem abarca os seguintes parâmetros: o contexto de produção e o conteúdo temático para que haja a interação.

\footnotetext{
uma ação da linguagem consiste em identificar os valores precisos que são atribuídos pelo agente-produtor a cada um dos parâmetros do contexto aos elementos do conteúdo temático mobilizado... constrói uma certa representação... e intervém verbalmente (BRONCKART, 1999/2012, p. 99).
}

A ação da linguagem é uma "base de orientação" para que o autor possa interagir com sucesso, ou seja, escolher corretamente o gênero a ser utilizado para comunicação. Para saber que foi bem sucedido no gênero que escolheu para interação, o emissor deverá saber se o objetivo apontado foi atingido, se foi apropriado aos valores sociais do lugar e se agenciou uma "imagem de si” (BRONCKART, 1999/2012, p. 101).

É por meio da escolha do gênero que o indivíduo irá interagir socialmente em sua comunidade. As mudanças do gênero se dá por estas situações de produção, sendo que em cada situação o gênero se apropria de certo modo e pela sua situação histórica, Bronckart (1999/2012) defende que o gênero se modifica ao longo do tempo.

\section{O GÊNERO ESCOLHIDO}

Para a análise do contexto de produção foram escolhidos como corpus 10 vídeos, que já fazem parte de um corpus de análise da dissertação no programa de mestrado em Estudos da Linguagem da UEL. O gênero escolhido foi este pelo contexto didático disposto, uma turma de terceiro e quarto anos do Ensino Médio técnico em meio-ambiente e com baixo nível em língua inglesa.

O gênero é denominado videoclipe de anúncio publicitário institucional, pois é um meio de cultura de massa que se utiliza de efeitos para trabalhar por causas (CONNOR, 1992). Os vídeos se apropriam da categoria videoclipe tendo como principais características o incentivo de ações progressistas, as imagens são um complemento às palavras e que muitas vezes ou na maioria delas podem ser músicas e que causam um efeito social. Se enquadra na categoria videoclipe socialmente ativo os quais se opõem a valores impostos pela sociedade tentando dessa forma influenciar atitudes para mudar as visões já construídas (CONNOR, 1992). Esse estilo de vídeo 
visa o controle de uma necessidade comunitária expondo uma ideia que acarretará em uma decisão de alteração de atitude. Apresentamos abaixo um quadro descritivo destes vídeos elaborado para o trabalho de mestrado. Os vídeos foram devidamente separados em categorias para a melhor visualização da intenção do ator.

Quadro 1. Panorama Geral dos Vídeos

\begin{tabular}{|c|c|c|c|c|}
\hline Organização & Título & $\begin{array}{l}\text { Tempo } \\
\text { do } \\
\text { vídeo }\end{array}$ & $\begin{array}{l}\text { Data de } \\
\text { produção }\end{array}$ & Descrição \\
\hline Greenpeace & $\begin{array}{l}\text { Breath in } \\
\text { Breath out }\end{array}$ & $59 \prime$ & $23 / 11 / 2006$ & $\begin{array}{l}\text { Composto por diferentes cenas da natureza, } \\
\text { como montanhas, pedras, geleiras, desertos e por } \\
\text { rios, lago e mangues. O som é de respiração. } \\
\text { Quando é inspiração, o cenário se enche de } \\
\text { água e quando é expiracão se esvazia. }\end{array}$ \\
\hline Autor desconhecido & $\begin{array}{l}\text { Global } \\
\text { Warming }\end{array}$ & 3'09', & $31 / 08 / 2007$ & $\begin{array}{l}\text { As primeiras cenas são do planeta Terra em } \\
\text { situação normal e depois com o aquecimento } \\
\text { global. São apresentadas tabelas das alterações } \\
\text { climáticas, e imagens comparando em datas de } \\
\text { quando era um local na natureza e como se } \\
\text { tornou com a destruição ambiental. O planeta } \\
\text { em chamas, as geleiras derretendo, cenas } \\
\text { naturais no geral de destruição e estáveis. O } \\
\text { videoclipe finaliza com uma frase de } \\
\text { conscientização. O videoclipe possui como trilha } \\
\text { sonora a música Hero de NickelBack. }\end{array}$ \\
\hline WWF & $\begin{array}{ll}\text { Uma } & \text { hora } \\
\text { volta } & \text { para } \\
\text { você } & \end{array}$ & $1 ’ 01 ”$ & $\begin{array}{l}\text { Sem data } \\
\text { de } \\
\text { produção }\end{array}$ & $\begin{array}{l}\text { A animação se inicia com um homem cortando } \\
\text { uma árvore com uma serra elétrica. Ao cair, ela } \\
\text { bate em outras as derrubando. Chegando na } \\
\text { quinta árvore, ela bloqueia a passagem de um rio } \\
\text { que é desviado, os peixes morrem e o desvio dá } \\
\text { de encontro a um trator, que derruba uma pedra } \\
\text { em uma ponte derrubando um carro cheio de } \\
\text { petróleo. O combustível atinge animais que } \\
\text { chegam até as geleiras quebrando-as e causando } \\
\text { uma enorme onda que causa uma inundação. Os } \\
\text { incidentes vão aumentando até que as árvores, } \\
\text { que estão em volta do planeta Terra, vão caindo } \\
\text { e voltam ao homem do início. A música de } \\
\text { fundo é intitulada Money makes the world GO } \\
\text { round. }\end{array}$ \\
\hline Greenpeace & $\begin{array}{l}\text { Inspiring } \\
\text { action }\end{array}$ & 3 & $21 / 04 / 2009$ & $\begin{array}{l}\text { Cenas do espaço, galáxias e estrelas são } \\
\text { apresentadas no início do vídeo seguidas da } \\
\text { imagem do planeta Terra. Posteriormente a esta } \\
\text { imagem, seguem cenas da natureza sendo de } \\
\text { alguma forma destruída, pelo homem ou não, } \\
\text { como homens pescando, geleiras derretendo, } \\
\text { peixes morrendo em rios, árvores sendo } \\
\text { cortadas, entre outras. Aparece um balão do } \\
\text { Greenpeace com a imagem do planeta e a luta } \\
\text { para parar com todo esse vandalismo e pessoas } \\
\text { tentando salvar o meio ambiente por meio de } \\
\text { mensagens de conscientização. }\end{array}$ \\
\hline Greenpeace & Earth & 1'30'” & $21 / 04 / 2010$ & O vídeo inicia com frases de consumo. Mãos \\
\hline
\end{tabular}

\footnotetext{
${ }^{4}$ As datas de produção dos vídeos foram deduzidas pela data de publicação no site Youtube, pelos originais produtores dos vídeos em seus devidos canais.
} 


\begin{tabular}{|c|c|c|c|c|}
\hline & $\begin{array}{l}\text { give Earth a } \\
\text { hand }\end{array}$ & & & $\begin{array}{l}\text { aparecem tentando tocar os produtos. Essas } \\
\text { frases são substituídas por frases de coisas } \\
\text { naturais, como árvores, ar puro, etc. Seguem-se } \\
\text { imagens das mãos formando todos os ambientes } \\
\text { naturais que são desejados na frase inicial. Uma } \\
\text { plantação de trigo, pássaros florestas e rios, } \\
\text { oceanos, baleias e cápsulas polares. Por fim, } \\
\text { aparece a imagem do sol e da Terra como se } \\
\text { fossem as mãos mas produzidas graficamente. E } \\
\text { uma mão apoiando a frase: Give Earth a hand }{ }^{5} \text {. }\end{array}$ \\
\hline Greenpeace & Genius ideas & $52^{\prime \prime}$ & $\begin{array}{l}\text { Sem data } \\
\text { de } \\
\text { produção }\end{array}$ & $\begin{array}{l}\text { É uma sequência de três vídeos. O primeiro } \\
\text { sobre o cientista Einstein que aparece na } \\
\text { primeira cena fazendo cálculos em um quadro } \\
\text { negro, quando tem uma ideia, sobre sua cabeça } \\
\text { surge a lâmpada amarela. No mesmo momento } \\
\text { desce um homem em uma corda que troca a } \\
\text { lâmpada por uma incandescente. O segundo é } \\
\text { sobre Newton que está debaixo de uma árvore e } \\
\text { quando a maçã cai em sua cabeça acontece o } \\
\text { mesmo que no vídeo anterior, a lâmpada é } \\
\text { substituída. E o último é sobre Archimedes, } \\
\text { que está tomando banho e surge-lhe uma idéia: } \\
\text { aparecem três homenzinhos de barco e trocam a } \\
\text { sua lâmpada também. }\end{array}$ \\
\hline Greenpeace & $\begin{array}{l}\text { Human life } \\
\text { commercial }\end{array}$ & $33^{\prime \prime}$ & $\begin{array}{l}\text { Sem data } \\
\text { de } \\
\text { produção }\end{array}$ & $\begin{array}{l}\text { O vídeo inicia-se com um bebê sentado em um } \\
\text { cenário cheio de geleiras na Argentina no ano de } \\
\text { 1928. A imagem se aproxima e o bebê se torna } \\
\text { uma criança que começa um discurso sobre o } \\
\text { meio ambiente. A imagem é acelerada, a pessoa } \\
\text { na cena vai envelhecendo com a aceleração se } \\
\text { tornando adolescente, jovem, adulto e idoso e } \\
\text { com isso a imagem das geleiras também vão se } \\
\text { modificando e derretendo com a rapidez da } \\
\text { passagem do tempo. }\end{array}$ \\
\hline WWF & $\begin{array}{l}\text { Change the } \\
\text { way you think }\end{array}$ & 1'32"' & 03/02/2009 & $\begin{array}{l}\text { A cena começa com uma frase que é substituída } \\
\text { por um copo de café. Essa imagem é seguida por } \\
\text { frases de quais são os produtos necessários para } \\
\text { o consumo do café matinal. Surge um copo e } \\
\text { uma mão o abre, posteriormente, uma seta que } \\
\text { aponta para um reservatório de água, que vai } \\
\text { sendo preenchido pelos elementos que se } \\
\text { encontram no café. A imagem é substituída por } \\
\text { outra frase e água como se fosse um rio } \\
\text { correndo. As frases vão sendo substituídas e as } \\
\text { imagens também. São mostrados uma porção de } \\
\text { copos de café. Logo após a imagem do planeta } \\
\text { Terra. O copo novamente e uma mão o retira da } \\
\text { cena. Um grão de café é mostrado e gotas de } \\
\text { água e novamente aparece a imagem da água } \\
\text { correndo como se fosse um rio. A imagem de } \\
\text { várias pessoas vestidas com ternos. E finaliza } \\
\text { com uma frase titulo do vídeo. }\end{array}$ \\
\hline WWF & $\begin{array}{l}\text { Change the } \\
\text { way you think } \\
\text { about food }\end{array}$ & 2'17'” & $12 / 10 / 2011$ & $\begin{array}{l}\text { Inicia-se com o título e a palavra everything }{ }^{6} \text { é } \\
\text { substituída pela palavra food }{ }^{7} \text {. São mostrados } \\
\text { sinais matemáticos e, em seguida, a imagem de }\end{array}$ \\
\hline
\end{tabular}

\footnotetext{
${ }^{5}$ Dê uma mão à Terra.

6 Tudo

${ }^{7}$ Comida
} 


\begin{tabular}{|c|c|c|c|c|}
\hline & & & & $\begin{array}{l}\text { muitas pessoas e a palavra população x o } \\
\text { consumo, que é representada pela imagem de } \\
\text { vários pratos e talheres, igual à capacidade do } \\
\text { planeta. Novamente, é mostrado o sinal de igual, } \\
\text { a Terra inteira e a metade dela. Sua metade é } \\
\text { retida de cena e aparece apenas a Terra. O } \\
\text { planeta Terra é devorado por mordidas, porém a } \\
\text { boca não aparece. Mais uma vez aparece a } \\
\text { imagem da Terra e agora é dividida em pedaços } \\
\text { com cortes. Cada pedaço cortado se torna negro } \\
\text { e é preenchido pelos alimentos que consumimos. } \\
\text { Fica na cena apenas uma fatia da Terra que é } \\
\text { cortada em pedaços também, com o mesmo } \\
\text { efeito e substituída por palavras como desertos, } \\
\text { lagos e outras. Águas descem na tela como se } \\
\text { fossem um rio, seguidas de gotas de água. Em } \\
\text { seguida, aparecem na tela várias gotas e são } \\
\text { substituídas por galões de água. Surge a imagem } \\
\text { de um saco de arroz, gotas de água, minerais, e } \\
\text { outros produtos que são necessários para a } \\
\text { industrialização de alimentos. O videoclipe é } \\
\text { finalizado com o símbolo de sustentabilidade em } \\
\text { movimento e a frase título do vídeo: Change the } \\
\text { way you think about food. }\end{array}$ \\
\hline WWF & $\begin{array}{l}\text { Change the } \\
\text { way you think } \\
\text { about your } \\
\text { laptop }\end{array}$ & 2'18' & $01 / 11 / 2011$ & $\begin{array}{l}\text { Como todos os vídeos dessa categoria ele inicia } \\
\text { com a frase que é título do vídeo. Aparece a } \\
\text { imagem de um notebook seguida dos } \\
\text { componentes que vão dentro dele, vidro, } \\
\text { plástico, alumínio, efeitos ultravioletas, energia, } \\
\text { água e a floresta. Há também a imagem de uma } \\
\text { lata de alumínio e o planeta Terra, destacando o } \\
\text { Brasil, que representa a floresta amazônica com } \\
\text { a imagem de árvores repetidas vezes em uma } \\
\text { cena. Em seguida, linhas que representam a } \\
\text { imagem de um rio e logo abaixo uma barreira. } \\
\text { Ao lado dessa imagem aparecem vários galões } \\
\text { de água. Posteriormente, raios que e um cabo de } \\
\text { energia que sai deles e se ligam a imagem de um } \\
\text { notebook. As imagens retornam gradativamente } \\
\text { na sequência anterior, barreira, rio e floresta, } \\
\text { porém, a água inunda a floresta e aparece a } \\
\text { imagem do sol, diminui o fluxo de água e essa } \\
\text { imagem é substituída pelo notebook novamente } \\
\text { com a informação que para um aparelho é } \\
\text { necessário a destruição de } 0,28 \text { m2 de floresta } \\
\text { amazônica. E por fim e finalizado com a frase } \\
\text { título do vídeo. }\end{array}$ \\
\hline
\end{tabular}

A sequência da análise será contexto físico, contexto social e conteúdo temático do vídeo. Concernente ao contexto físico, lugar de produção os vídeos Breath in Breath out e Inspiring action foram feitos em lugares abertos com a filmagem de cenários naturais e, posteriormente, em um escritório com computador para a montagem do vídeo. Os vídeos Change 
de way you think about food, Change the way you think about you laptop e Global Warming foram produzidos em um espaço com computador para a edição do vídeo. O vídeo Change the way you think foi produzido em um estúdio de gravação de imagens e espaço para montagem de cenas no computador. O vídeo Uma hora volta pra você foi elaborado em um estúdio de gravação de vídeos de animação. O Earth day: give Earth a hand foi feito em um escritório com computador para montagens de imagens, estúdio de gravação para as imagens das mãos. Genius ideas foi montado em um estúdio de montagem de cenas de animação em massinha. E por fim, o vídeo Human life commercial foi elaborado em um estúdio de gravação e, posteriormente, em um escritório com computador onde foi possível editar e montar as imagens e procurar outras cenas necessárias.

Para o tempo de produção os vídeos Breath in Breath out e Human life commercial levaram aproximadamente duas semanas levando-se em consideração o prazo de filmagens e a montagem. Os vídeos Uma hora volta pra você, Inspiring action e Earth day: give Earth a hand por volta de um mês para ficar pronto, o primeiro considerando a montagem das massinhas para o efeito de animação e os outros dois a montagem das cenas. O videoclipe Genius Ideas, sendo três videoclipes em apenas um e produzidos por massinha de modelar, levou aproximadamente três meses para ser produzido, um mês cada vídeo, para a montagem das massas e a mudança de posição destas. Os vídeos Change the way you think, Change the way you think about food, Change the way you think about your laptop e Global warming levaram em média uma semana para sua produção. O emissor dos vídeos Breath in Breath out, Inspiring action, Earth day, Genius ideas e Human life commercial é a ONG Greenpeace, dos vídeos Uma hora volta pra você, Change the way you think, Change the way you think about food, Change the way you think about your laptop é a ONG WWF e do vídeo Global warming é de um ativista ambiental.

A população que tem acesso à internet e ao site Youtube são os receptores dos vídeos Breath in Breath out, Inspiring action, Earth day, Genius ideas e Human life commercial e os que têm acesso à rede aberta de TV são os receptores do vídeo Uma hora volta pra você. Os receptores do vídeo Change the way you think é a população consumidora de bebidas quentes no período da manhã. Change the way you think about food tem como receptor a população adulta, Change the way you think about your laptop além da população adulta tem ainda a jovem. E o vídeo Global warming tem como receptor a população em geral.

Passando ao contexto social, mais especificamente o lugar social do emissor, todos os vídeos têm como instituição organização não-governamental de defesa ambiental, exceto o vídeo Global warming o lugar social do emissor é de um cidadão na luta contra a destruição ambiental. 
Em todos os vídeos, a posição social do emissor é a de um defensor da natureza e ativista e a posição social do receptor nos vídeos breath in Breath out e Inspiring action é a de um cidadão responsável pelas mudanças de atitude. Além dessa posição no vídeo Earth Day, o receptor deve estar disposto a ajudar a natureza e, no vídeo Uma hora volta pra você, é para adultos e crianças. No vídeo Genius ideas o cidadão que tenha acesso a materiais de construção ou que tenha sua moradia e consuma lâmpadas são os receptores e desempenham o papel social de consumidores conscientes. Em Human life commercial, os jovens que ainda não sejam casados ou casados recentemente e que ainda constituirão família são responsáveis pela preservação para que as próximas gerações possam aproveitar a natureza da mesma forma. Pessoas que consomem bebidas todas as manhãs quando vão ao trabalho, hábito muito comum em cidades maiores, são os responsáveis pelo controle do consumo excessivo de bebidas e o seu papel social no vídeo Change the way you think. Da mesma forma os que consomem alimentos sendo jovens e adultos no vídeo Change the way you think about food. O papel social dos receptores do vídeo Change the way you think about your laptop é o do consumo consciente de produtos eletrônicos. E por fim, a consciência de pessoas que podem ajudar a natureza no vídeo Global warming.

Ainda no que diz respeito ao contexto do mundo social cada vídeo tem um objetivo na interação. Breath in Breath out tem o objetivo de mostrar para as pessoas que com as mudanças das nossas atitudes podemos preservar os oceanos que são os responsáveis pela produção de boa parte do oxigênio que respiramos, como informa a última frase do vídeo: Half of the oxygen we breathe comes from our oceans ${ }^{8}$. O vídeo Uma hora volta pra você demonstra que são as atitudes dos seres humanos que têm prejudicado a natureza, que tudo que fazemos contra ela se volta contra nós com todas as alterações climáticas, como um efeito dominó. É necessária a mudança de atitude antes que seja tarde. A mesma mensagem traz o anúncio do Human life commercial pedindo às pessoas que mudem sua atitude caso contrário a natureza não suportará. Inspiring action mostra à população todas as atitudes que têm sido tomadas pelas pessoas contra a natureza, a pesca ilegal, o desmatamento, etc. E a luta contra isso por parte da ONG Greenpeace a entender que unidos podemos mudar essa situação. O vídeo Earth day tem a mesma intenção do anterior, mostrar as pessoas que as ações devem partir do social, cada um faz a sua parte mas principalmente com relação à luta contra o consumismo. Genius Ideas procura conscientizar as pessoas com relação a compra de produtos de menos consumo elétrico, faz uma co-relação com gênios como Einstein metaforizando que se a pessoa for tão inteligente quanto ele fará uso de produtos bons que geram menor consumo. Os três vídeos Change the way you think, Change the

\footnotetext{
${ }^{8}$ Metade do oxigênio que respiramos vem dos nossos oceanos.
} 
way you think about food e Change the way you think about you laptop têm o objetivo de alertar as pessoas sobre o consumo excessivo de três produtos sendo respectivamente bebidas, comida e produtos eletrônicos, mais especificamente notebooks. Os videoclipes desta categoria visa alertar as pessoas que o consumo de coisas que são normais no nosso cotidiano pode também prejudicar o meio ambiente se não consumidos de forma consciente. Por fim, Global warming procura mostrar as pessoas que a natureza está sendo destruída e algo precisa ser feito. Passamos para a análise do conteúdo temático.

Em geral, os conteúdos dos videoclipes de anúncio publicitário institucional que analisamos são preservação do meio ambiente e destruição ambiental. Os vídeos Inspiring action, Earth day, Genius ideas, Change the way you think, Change the way you think about food, Change the way you think about you laptop e Global warming visam a mudança de atitude. Os vídeos Change the way you think, Change the way you think about food, Change the way you think about your laptop e Earth day tem, por sua vez, como conteúdo temático o consumo excessivo. Já Human life commercial e Genius ideas têm como principal tema a mudança climática. O vídeo Human life commercial tem como conteúdo temático o derretimento das geleiras e consequentemente o aumento do nível do mar. Outro vídeo que tem como conteúdo os oceanos é o Breath in Breath out. Por fim, o conteúdo do vídeo Uma hora volta pra você é a consequência dos nossos atos como sendo o principal fator prejudicial à natureza.

Como citamos anteriormente, esse trabalho se atém a apresentação da análise do contexto de produção do gênero VAPI e compõe o trabalho de dissertação de mestrado. Passamos para as conclusões dessa análise.

\section{CONCLUSÃO}

Como atores que se apropriam da linguagem, em cada situação de uso devemos fazer uma seleção de qual o melhor texto a ser utilizado para, então, interagirmos. Essa apropriação toma como princípio de análise o contexto de produção. No momento de interação social, analisamos rapidamente o contexto para utilizarmos o texto de forma correta.

Os videoclipes de anúncio publicitário institucional visam principalmente à conscientização populacional para a preservação do meio ambiente. Têm como principais características do contexto de produção, cenários naturais e para edição se utiliza um espaço no qual haja um computador para a edição das cenas. Em se tratando de montagens de animação apenas o espaço para a gravação se faz necessário. O tempo de produção varia de acordo com a intenção do vídeo. 
O emissor sempre está relacionado a uma pessoa que luta contra a destruição ambiental e por esse motivo o conteúdo temático principal estão também ligadas a isso, bem como a preservação, ao controle do consumo excessivo de produtos, as mudanças climáticas, entre outras situações que prejudicam o meio ambiente. Os receptores desses vídeos são pessoas que têm acesso à internet e que podem, com a mudança de suas atitudes e a sua conscientização, tentar mudar a situação ambiental atual. VAPIs são geralmente produzidos por ONGs, mas podem também ser produzidos por outros cidadãos que possuem a mesma ideologia. O gênero tem como objetivo disseminar uma nova ideologia pela qual as pessoas possam mudar suas atitudes e para que as mudanças climáticas e toda a destruição ambiental tenham um fim.

Visamos por meio dessa publicação disponibilizar o material de análise do gênero para que outros professores possam produzir seus modelos didáticos e, assim, produzir sequências didáticas para o ensino de Língua Inglesa.

\section{REFERÊNCIAS}

BRONCKART, J.P. Atividade de linguagem, discurso e desenvolvimento humano. Campinas, SP: Mercados de Letras, 2006.

O agir nos discursos: das concepções teóricas às concepções dos trabalhadores. Campinas, SP: Mercado de Letras, 2008.

Atividade de linguagem, textos e discurso: por um interacionismo sociodiscursivo. 2 ed. 2. reimpr. São Paulo: EDUC, 2012.

ÉRNICA, M. Hipótese sobre o funcionamento dos mundo e dos tipos discursivos nos textos artísticos. In: GUIMARÃES, A. M. de M. et al. O interacionismo sociodiscursivo: questões epistemológicas e metodológicas. Campinas, SP: Mercado de Letras, 2007.

NASCIMENTO, E.L.; CRISTOVÃO, V. L. L. Gêneros textuais e ensino: contribuições do interacionismo sócio-discursivo. In: KARWOSKI, A. M. et.al. Gêneros textuais: reflexões e ensino. Rio de Janeiro: Lucerna, 2006.

PEREIRA, L.; GRAÇA, L. Da conceptualização do contexto de produção e da sua produtividade na didáctica da escrita. In: GUIMARÃES, A. M. de M. et al. O interacionismo sociodiscursivo: questões epistemológicas e metodológicas. Campinas, SP: Mercado de letras, 2007. QUEVEDO-CAMARGO, G.P. Análise sociodiscursiva de uma amostra do exame TKT. In: CRISTOVÃO, V. L. L. Estudos da linguagem à luz do interacionismo sociodiscursivo. Londrina: UEL, 2008, p. 127-144.

SCHNEUWLY, B.. Gêneros e tipos de discurso: considerações psicológicas e ontogenéticas. In: SCHNEUWLY, B.; DOLZ, J. Gêneros orais e escritos na escola. Campinas, SP: Mercado de Letras, 2004.

Greenpeace. Breath in Breath out. Disponível em:

<http://www.youtube.com/watch?v=tzcGFUsL4HM> Acesso em: 14 de dez de 2012

Greenpeace. Uma hora volta pra você. Disponível em:

<http://www.youtube.com/watch?v=FfbSxW3wPUQ> Acesso em: 14 de dez de 2012

Greenpeace. Inspiring action. Disponível em:

<http://www.youtube.com/watch?v=zVu9eawb1QY> Acesso em: 14 de dez de 2012 
Greenpeace. Earth day: Give Earth a hand. Disponível em:

<http://www.youtube.com/watch?v=Ep9MFiWXR8M> Acesso em: 14 de dez de 2012

Greenpeace. Genius ideas. Disponível em: 〈http://www.youtube.com/watch?v=clIhgIhCfqM> Acesso em: 14 de dez de 2012

Greenpeace. Human life commercial. Disponível em:

<http://www.youtube.com/watch?v=nMNu68gsAPA> Acesso em: 14 de dez de 2012

Greenpeace. Change the way you think. Disponível em:

<http://www.youtube.com/watch?v=nDTmjR_GG1w> Acesso em: 14 de dez de 2012

Greenpeace. Change the way you think about food. Disponível em:

<http://www.youtube.com/watch?v=s_JLmxhnpNY> Acesso em: 14 de dez de 2012

Greenpeace. Change the way you think about your laptop. Disponível em:

<http://www.youtube.com/watch?v=bzQgB6eBj9c> Acesso em: 14 de dez de 2012

Global Warming. Disponível em: <http://www.youtube.com/watch?v=ofEexHBW3j4> Acesso em: 14 de dez de 2012 